\title{
Effects of prey abundance and light intensity on nutrition of a mixotrophic flagellate and its competitive relationship with an obligate heterotroph
}

\author{
Carina Pålsson*, Cesar Daniel \\ Department of Ecology/Limnology, Ecology Building, 22362 Lund, Sweden
}

\begin{abstract}
The mixotroph Poterioochromonas malhamensis was grown in batch and semicontinuous cultures in order to examine the dependence of phagotrophy versus phototrophy at bacterial densities similar to those found in oligo- and mesotrophic lakes in combination with differing light regimes. In addition, the growth rates and biomass accumulation of the mixotroph were compared to those of the heterotroph Spumella elongata grown under similar conditions. In P. malhamensis, primary production rates and cell-specific chlorophyll a concentrations were significantly higher when grown at low bacterial densities, and the carbon cell ${ }^{-1}$ gained by photosynthesis corresponded to $79 \%$ of the carbon cell $^{-1}$ gained by bacterial ingestion. Furthermore, due to a longer exponential growth phase, cell densities and biomass of $P$. malhamensis were significantly higher when the mixotroph was cultured in high light than in darkness. As a result, the cumulative biomass of the mixotroph was significantly higher in the light treatments than the biomass of the heterotroph at similar bacterial densities. These results suggest that photosynthesis may contribute more to the nutrition of $P$. malhamensis in lakes with low bacterial abundances than previously suggested, and that the mixotroph's capacity for photosynthesis enables it to dominate in terms of biomass over the heterotroph.
\end{abstract}

KEY WORDS: Poterioochromonas malhamensis - Spumella elongata · Phagotrophy · Photosynthesis · Competition

Resale or republication not permitted without written consent of the publisher

\section{INTRODUCTION}

Heterotrophic flagellates are major grazers of bacteria and thereby play an important role in the recycling of nutrients in the microbial loop (Laybourn-Parry \& Parry 1995). Species with mixotrophic nutrition, whereby phototrophy and phagotrophy are combined, have also been found to exert a significant grazing pressure on bacteria in many kinds of waters (Bennett et al. 1990, Isaksson et al. 1999, Hitchman \& Jones 2000). Among the mixotrophs, the nutritional requirements as well as the reliance on phototrophy versus phagotrophy vary considerably between species and are influenced by a wide range of environmental parameters (Holen \& Boraas 1995, Granéli \& Carlsson 1998). Thus there are several potential advantages of mixotrophy, including the ability to acquire carbon when light is limited or to obtain inorganic nutrients or growth factors to support photosynthesis (Bird \& Kalff 1987, Nygaard \& Tobiesen 1993). Due to the ability of the mixotrophs to combine photosynthesis and phagotrophy, they compete with obligate autotrophs for light and inorganic nutrients and with obligate heterotrophs for particulate organic nutrients. Yet little is known about these competitive interactions and very few experimental (Rothhaupt 1996a, 1997) or theoretical (Thingstad et al. 1996, Stickney et al. 2000) studies exist in which the competitive relationship between a mixotroph and an obligate heterotroph or autotroph has been examined. However, mixotrophs have been suggested to have lower growth rates than their obligate competitors due to extra costs incurred by a 
mixotrophic nutrition (Raven 1995, 1997). Thus, in the competitive relationship between mixotrophs and obligate heterotrophs, the former are believed to have an advantage only when prey densities are low and light is available (Jones 2000).

The aims of this study were (1) to examine and compare growth and biomass accumulation of the mixotrophic flagellate Poterioochromonas malhamensis and the heterotrophic flagellate Spumella elongata grown under similar conditions in batch and semi-continuous cultures and (2) to further investigate the effect of light and bacterial densities similar to those found in oligotrophic and mesotrophic lakes on the reliance of phagotrophy versus phototrophy in $P$. malhamensis. Small nanoflagellates belonging to the genus Spumella spp. are very abundant in many lakes (Auer \& Arndt 2001), and have been reported to be important consumers of bacteria (Weisse 2002). The mixotrophs Poterioochromonas spp. and closely related Ochromonas spp. are abundant bacterivores that, as a result of their nutritional flexibility, have received considerable interest over the years (e.g. Myers \& Graham 1956, Handa et al. 1981, Caron et al. 1990, Lewitus \& Caron 1991, Sanders et al. 2001). P. malhamensis is an efficient bacterivore, and it has been suggested that the flagellate relies on phagotrophy to obtain most or all of the energy used for metabolism and growth (Caron et al. 1990). Furthermore, when actively growing on bacteria, light does not seem to influence growth rates in this mixotroph, and research has suggested that photosynthesis is important only for survival in the absence of sufficient bacterial densities for heterotrophic growth (Sanders et al. 1990).

\section{MATERIALS AND METHODS}

Poterioochromonas malhamensis was kindly provided by D. A. Holen, Pennsylvania State University (see Holen 1999 for isolation details), and cultivated in sterile organic Ochromonas growth medium (Starr 1978) at $40 \mu \mathrm{E} \mathrm{m}{ }^{-2} \mathrm{~s}^{-1}$ under a light:dark cycle of 18:6 h. Spumella elongata (CCAP 955/1) was maintained in the inorganic, artificial freshwater MWC medium (modified Woods Hole Medium; Guillard \& Lorenzen 1972) enriched with bacteria and wheat grains. Cultivation and experiments were done in temperaturecontrolled rooms at $20 \pm 1{ }^{\circ} \mathrm{C}$. All experiments were performed in MWC medium. To ensure a similar bacterial community throughout the experiment, all bacteria used in batch and semi-continuous cultures as well as for measuring ingestion rates originated from the same culture. A batch culture with a natural bacterial community from Lake Sövdesjön (southern Sweden) was attained by sterile filtration $(0.2 \mu \mathrm{m}$; Schleicher \&
Schuell) and subsequent inoculation of filtered (Whatman GF/F) lake water. Subsamples from the culture $(4 \mathrm{ml})$ were then cryogenically preserved $\left(-80^{\circ} \mathrm{C}\right)$ with the addition of DMSO (final concentration 6.5\%) and used as inoculum for all bacterial cultures. In order to produce bacterial prey, the MWC medium was enriched with glucose at a concentration of 1 or $10 \mathrm{mg}$ glucose $\mathrm{l}^{-1}$ depending on the preferred bacterial density (low, medium or high). The bacteria were maintained in continuous cultures at a dilution rate of approximately $0.45 \mathrm{~d}^{-1}$. The mean cell volume of the cultured bacteria was $0.302( \pm 0.048) \mu^{3}$ and did not change during the experiment.

Flagellate batch cultures. To estimate maximum exponential growth rates, Poterioochromonas malhamensis and Spumella elongata were grown in the dark in batch cultures $(450 \mathrm{ml})$ separately as well as together (referred to as PotMono, SpuMono and mixed). Each treatment was performed with 2 replicates, and the cultures were continuously mixed on a horizontal shaker at $100 \mathrm{U} \mathrm{min}{ }^{-1}$. Starting densities of bacteria were approximately $12 \times 10^{6}$ bacteria $\mathrm{ml}^{-1}$ in the PotMono treatment and $9.5 \times 10^{6}$ bacteria $\mathrm{ml}^{-1}$ in the SpuMono and mixed treatments. For the flagellates, the starting densities were approximately $1.1 \times 10^{3}$ and $0.65 \times 10^{3}$ cells $\mathrm{ml}^{-1}$ of $P$. malhamensis in the PotMono and mixed treatments respectively and $5 \times 10^{3}$ and $2.2 \times 10^{3}$ cells $\mathrm{ml}^{-1}$ of $S$. elongata in the SpuMono and mixed treatments. Samples (preserved with Lugol's acid solution and sterile filtered formalin at $3 \%$ final concentration) were removed at least every $24 \mathrm{~h}$ over $10 \mathrm{~d}$ and at closer intervals (6 to $12 \mathrm{~h}$ ) on Days 1 to 3 . Bacterial densities were obtained from the formalin-preserved samples, while flagellate densities were counted live using a FACSort (Becton Dickinson) flow cytometer. P. malhamensis was identified based on its chlorophyll fluorescence, whereas bacteria and $S$. elongata were stained with CYTO-13 (del Giorgio et al. 1996). For both flagellates and bacteria, flow cytometric measurements were checked against manual countings of Lugol-preserved and DAPI-stained samples respectively. Maximum growth rates $\left(\mu_{\max }\right)$ were determined by linear regressions of the natural log of cell densities versus time during the exponential phase. Flagellate cell volumes on Day 2 were measured using an ocular micrometer and calculated assuming spherical cells (Wetzel \& Likens 1991). Flagellate yield was calculated as the increase in flagellate density divided by the decrease in bacterial density over time, assuming no bacterial growth and a volume to $\mathrm{C}$ conversion factor of $0.308 \mathrm{pg} \mathrm{C} \mathrm{m}^{-3}$ for bacteria (Fry 1988) and $0.2 \mathrm{pg} C$ $\mu \mathrm{m}^{-3}$ for flagellates (Wetzel \& Likens 1991).

Semi-continuous cultures. In addition to the batch cultures, Poterioochromonas malhamensis and Spumella elongata were grown in semi-continuous cul- 
tures in which their responses towards varied bacterial densities and light intensities ( $P$. malhamensis) were examined. In monocultures, $P$. malhamensis was exposed to 3 treatments with low light $\left(15 \mu \mathrm{E} \mathrm{m} \mathrm{m}^{-2} \mathrm{~s}^{-1}\right)$ in combination with the addition of low, medium or high mean bacterial densities $\left(0.5,2.4\right.$ and $8.2 \times 10^{6}$ bacteria $\mathrm{ml}^{-1}$, respectively), 1 treatment with high light $\left(155 \mu \mathrm{E} \mathrm{m}^{-2} \mathrm{~s}^{-1}\right)$ with medium bacterial density $(3.7 \times$ $10^{6}$ bacteria $\mathrm{ml}^{-1}$ ), and complete darkness (cultures wrapped in aluminum foil) with medium bacterial density $\left(3.3 \times 10^{6}\right.$ bacteria $\left.\mathrm{ml}^{-1}\right)$. In the light treatments, the light:dark cycle was 18:6 h. Prior to the start of each treatment, P. malhamensis was adapted to the prevailing light level for at least $30 \mathrm{~h}$. Monocultures of S. elongata were kept in the dark because of their heterotrophic mode of nutrition, and bacteria were added at 3 different densities $\left(1.4,3.9\right.$ and $10.0 \times 10^{6}$ bacteria $\mathrm{ml}^{-1}$; referred to as low, medium and high). All treatments were performed with 3 replicates and the cultures were continuously mixed on a horizontal shaker at $100 \mathrm{U} \mathrm{min}^{-1}$.

At the start of each treatment, $250 \mathrm{ml}$ of MWC medium containing the desired bacterial density were added to 3 borosilicate glass bottles (Pyrex) and inocu-

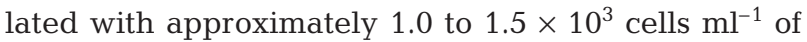
Poterioochromonas malhamensis or 0.6 to $2.0 \times 10^{3}$ cells $\mathrm{ml}^{-1}$ of Spumella elongata. Samples were removed every $12 \mathrm{~h}$ and replaced with fresh bacteria culture and MWC medium, corresponding to a dilution rate of $0.4 \mathrm{~d}^{-1}$. This dilution was equivalent to approximately 11 and $10 \%$, respectively, of the calculated $\mu_{\max }$ measured for the purely phagotrophically growing $P$. malhamensis and $S$. elongata in the batch cultures. The removed samples were preserved with formalin ( $2 \%)$ and Lugol's acid solution. Density counts of flagellates and bacteria were obtained from the formalin preserved samples using a FACSort (Becton Dickinson) flow cytometer (del Giorgio et al. 1996). For the flagellates, growth rates (0 to $48 \mathrm{~h}$ ) were calculated as described above for the exponential phase prior to reaching steady state. Cell volumes were calculated for flagellates sampled on Day 10. Total biomass on Day 10 was calculated as cell numbers $\times$ cell volume, whereas biomass in terms of carbon was calculated assuming a volume-to-carbon conversion of $0.2 \mathrm{pg}$ $\mu^{-3}$ (Wetzel \& Likens 1991). To obtain concentrations of chl a, aliquots (19 to $30 \mathrm{ml}$ ) from each replicate were filtered onto a GF/F filter (Whatman, $25 \mathrm{~mm}$ ) every $24 \mathrm{~h}$. The filters were stored frozen and the chl a was extracted in ethanol over night (Jespersen \& Christoffersen 1987). Chlorophyll a absorbance was measured on a Beckman DU 650 Spectrophotometer. Cellular chl a concentrations were calculated by dividing total chl a by flagellate density and chl a normalized to volume was calculated by dividing cell-specific concentrations with cell volume. Additionally, primary production rates in the cultures containing $P$. malhamensis were measured on Day 10 according to the ${ }^{14} \mathrm{C}$ incorporation method (Wetzel \& Likens 1991) using one $23 \mathrm{ml}$ glass vial for each replicate and a control consisting of equal volumes of culture from the 3 replicates. $\mathrm{H}^{14} \mathrm{CO}_{3}$ (Amersham CFA3, specific activity $58 \mathrm{mCi}(2.15 \mathrm{GBq})$ $\left.\mathrm{mmol}^{-1}\right)$ was added $(1.76 \mu \mathrm{Ci}$ final activity) and the vials were incubated for 3 to $4 \mathrm{~h}$. During incubation, all vials except the control (incubated in darkness) were exposed to the same light and temperature conditions as the semi-continuous cultures. Cell-specific primary production rates were calculated for each treatment by dividing the production rate $\mathrm{h}^{-1}$ with cell density. The carbon per cell gained by photosynthesis was calculated assuming primary production during $18 \mathrm{~h} \mathrm{~d}^{-1}$, whereas carbon per cell gained by bacterial ingestion was calculated based on the disappearance of bacteria during steady-state conditions, assuming no bacterial growth and a volume to $\mathrm{C}$ conversion factor of

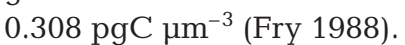

Ingestion rates of Poterioochromonas malhamensis and Spumella elongata were measured on Day 10 with fluorescently labeled bacteria that were stained using a modified version of the method of Sherr \& Sherr (1993), whereby Sybr ${ }^{\circledR}$ Gold (2.5× final concentration; absolute concentration not provided by Molecular Probes) was used instead of 5-(4,6-dichlorotriazin-2-yl) aminofluorescein (DTAF). Bacteria were stained for $15 \mathrm{~min}$ at $60^{\circ} \mathrm{C}$ in the dark and then centrifuged $(15 \mathrm{~min}, 14000 \times g)$ and washed twice $(0.2 \mu \mathrm{m}$ filtered MWC medium) to remove excess staining. Stained bacteria were resuspended in filtered $(0.2 \mu \mathrm{m}) \mathrm{MWC}$ medium and quantified by epifluorescence microscopy before being added to $100 \mathrm{ml}$ from each culture at a concentration equivalent to approximately 20 to $30 \%$ of bacterial densities in the semi-continuous cultures. The bottles were gently shaken and subsamples were removed from each replicate (Time zero). New subsamples were removed after 15 and $30 \mathrm{~min}$ in the $P$. malhamensis low-light:low-bacteria treatment and after 4, 8 and $15 \mathrm{~min}$ in all other treatments; $1 \mathrm{ml}$ from each subsample was immediately analyzed by flow cytometry. The 3 replicates from each treatment were used to calculate a mean ingestion rate according to Bratvold et al. (2000). During the grazing experiments, the bottles were exposed to conditions similar to those of the semi-continuous cultures. Analysis of covariance (ANCOVA) was used to compare interspecific differences in exponential-phase growth rates as well as steady-state cell densities and final biomass. For intraspecific analyses of differences between treatments, analysis of variance (ANOVA) was used, except for steady-state cell densities which were analysed using repeated-measures ANOVA. The raw data was 
log-transformed when necessary. All statistical analyses were performed using SPSS 10 software.

\section{RESULTS}

\section{Batch cultures (dark)}

The maximum growth rate of Spumella elongata $\left(4.19 \mathrm{~d}^{-1}\right)$ was slightly higher than that of Poterioochromonas malhamensis (3.53 $\mathrm{d}^{-1}$; Table 1). Also, peak abundances of $S$. elongata were higher than those of $P$. malhamensis (Table 1), as would be expected because of its smaller size (mean $2.5 \mu \mathrm{m}$ compared to $5.4 \mu \mathrm{m})$. In the mixed cultures, the densities of both species were considerably lower than in the monospecific cultures. Furthermore, densities of $S$. elongata decreased rapidly after approximately $30 \mathrm{~h}$ in the mixed cultures, and it was present at low densities (100 to 250 cells $\mathrm{ml}^{-1}$ ) from Day 4 onwards, whereas densities of $P$. malhamensis decreased slowly after reaching peak abundance. In the monocultures, flagellate yield in terms of C was 0.37 for P. malhamensis and 0.27 for $S$. elongata (Table 1).

Bacterial densities in the batch cultures decreased sharply as the flagellate cell numbers increased, and threshold densities for positive flagellate growth (as estimated by visual inspection of the graphical data) were 0.52 and $0.66 \times 10^{6}$ cells $\mathrm{ml}^{-1}$, respectively, for Poterioochromonas malhamensis and Spumella elongata in the monospecific cultures (Table 1). At minimum bacterial densities, the bacteria had been grazed down to approximately 3.5, 5.3 and $6.2 \%$ of starting densities in the PotMono, SpuMono and mixed cultures respectively. After this point, bacterial densities increased somewhat, and the highest mean bacterial density (Days 3 to 10) was obtained in the SpuMono cultures $\left(9.6 \times 10^{5}\right.$ cells $\left.\mathrm{ml}^{-1}\right)$ and the lowest in the PotMono cultures $\left(5.9 \times 10^{5}\right.$ cells $\left.\mathrm{ml}^{-1}\right)$.

Table 1. Poterioochromonas malhamensis and Spumella elongata. Comparison of means $(n=2)$ of flagellate maximum growth rates $\left(\mu_{\max } \mathrm{d}^{-1}\right)$, peak densities (cells ml $\mathrm{m}^{-1} \times 10^{3}$ ), yield (in terms of $\mathrm{C}$ ) and threshold bacterial densities for positive flagellate growth (cells $\mathrm{ml}^{-1} \times 10^{6}$ ) in dark batch cultures of $P$. malhamensis and $S$. elongata grown separately (mono) and together (mixed)

\begin{tabular}{|lcccc|}
\hline \multirow{2}{*}{ Parameter } & \multirow{2}{*}{$\begin{array}{c}\text { Mono } \\
\text { P. malhamensis }\end{array}$} & $\begin{array}{c}\text { Mono } \\
\text { S. elongata }\end{array}$ & P. malhamensis & S. elongata \\
\hline$\mu_{\max }$ & 3.53 & 4.19 & 3.46 & 4.61 \\
$\begin{array}{l}\text { Flagellate peak } \\
\quad \text { density }\end{array}$ & 57.80 & 184.60 & 13.30 & 102.10 \\
$\begin{array}{l}\text { Yield } \\
\text { Threshold bacterial } \\
\quad \text { density }\end{array}$ & 0.37 & & & \\
& 0.52 & 0.27 & & \\
\end{tabular}

\section{Semi-continuous cultures}

Exponential-phase growth, steady-state densities and final biomass

The exponential phase growth rates ( 0 to $48 \mathrm{~h}$ ) in the semi-continuous cultures were significantly higher for Spumella elongata (1.97 to $2.92 \mathrm{~d}^{-1}$; Fig. 1b) than for Poterioochromonas malhamensis (1.36 to $2.44 \mathrm{~d}^{-1}$; Fig. 1a) grown at similar bacterial densities (ANCOVA, $\mathrm{p}<0.001)$. For both species, growth rates were positively influenced by bacterial density and were significantly higher in the high-bacteria treatments compared to the low- and medium-bacteria treatments (ANOVA, p < 0.001). There were no significant differences in growth rates between $P$. malhamensis that received similar bacterial densities but were exposed to different light conditions (Fig. 1a). However, the exponential growth phase was considerably longer in the treatment receiving $155 \mu \mathrm{E} \mathrm{m}^{-2} \mathrm{~s}^{-1}$ (96 to $120 \mathrm{~h}$ ) compared to the low light $\left(15 \mu \mathrm{E} \mathrm{m} \mathrm{m}^{-2} \mathrm{~s}^{-1}\right)$ and dark treatments $(48 \mathrm{~h})$, resulting in cell densities in the highlight treatment that were approximately twice as high as those in the dark treatment (Fig. 1c). Overall, flagellate steady-state cell densities (shown as mean densities for Days 4 to 10; Fig. 1c,d) were higher for S. elongata than for $P$. malhamensis provided with similar bacterial concentrations (ANCOVA, p < 0.001). Furthermore, for both species, the steady-state carrying capacity increased with increasing bacterial concentrations ( $P$. malhamensis: $\mathrm{p}<0.001, \mathrm{R}^{2}=0.85$; S. elongata: $\mathrm{p}<0.001, \mathrm{R}^{2}=0.99$; Fig. $\left.1 \mathrm{c}, \mathrm{d}\right)$ and the highest flagellate abundances $\left(62.2 \times 10^{3} \mathrm{P}\right.$. malhamensis cells $\mathrm{ml}^{-1}, 132.0 \times 10^{3} \mathrm{~S}$. elongata cells $\mathrm{ml}^{-1}$; Table 2) were obtained in the treatments receiving high bacterial densities. Due to growth rates being slightly lower than the dilution rate, cell densities of $P$. malhamensis in the dark treatment and $S$. elongata in all treatments decreased somewhat from Day 4 onwards.

In contrast to cell densities, flagellate biomass on Day 10 was significantly higher in the Poterioochromonas malhamensis treatments receiving light

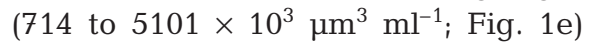
than in the Spumella elongata treat-

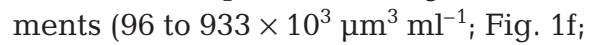
ANCOVA, $\mathrm{p}<0.001)$. The higher biomasses in the light treatments were a result of the larger volume of $P$. malhamensis than S. elongata cells. Furthermore, there was a positive correlation between final biomass and bacterial densities added for both the P. malhamensis light $\left(\mathrm{p}<0.001, \mathrm{R}^{2}=\right.$ 0.97 ) and the $S$. elongata treatments 


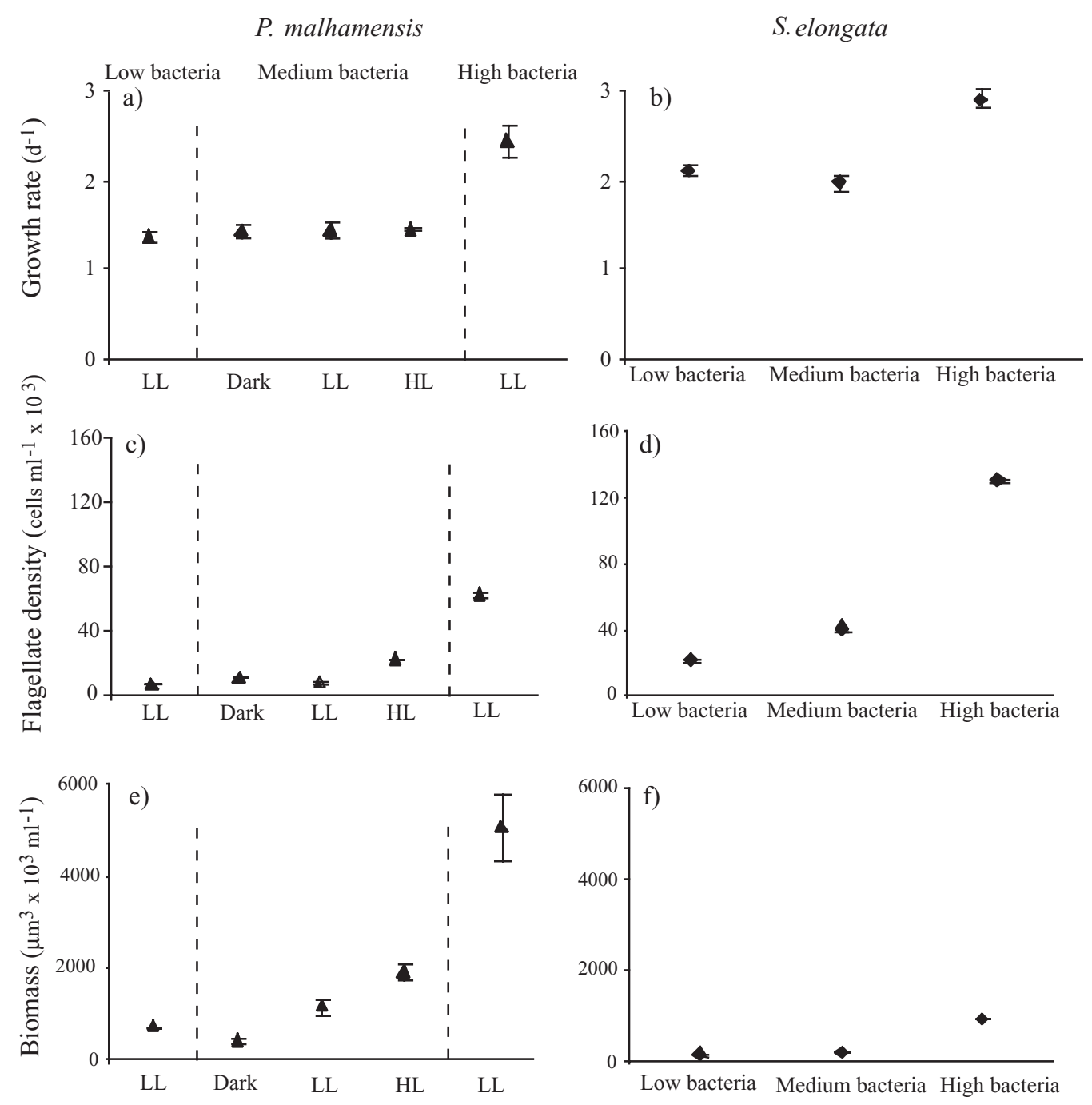

Fig. 1. Poterioochromonas malhamensis and Spumella elongata. (a,b) Semi-continuous exponential-phase (0 to $48 \mathrm{~h})$ growth rate, $(\mathrm{c}, \mathrm{d})$ steady-state (Days 4 to 10) density, and (e,f) cumulative biomass on Day 10 in response to low, medium or high bacterial densities (see Table 2), with darkness, low $\left(\mathrm{LL}=15 \mu \mathrm{E} \mathrm{m} \mathrm{m}^{-2} \mathrm{~s}^{-1}\right)$ or high $\left(\mathrm{HL}=155 \mu \mathrm{E} \mathrm{m} \mathrm{m}^{-2} \mathrm{~s}^{-1}\right)$ light intensity $(P$. malhamensis $)$ or darkness (S. elongata). All values are means $\pm 1 \mathrm{SE}(\mathrm{n}=3)$

Table 2. Poterioochromonas malhamensis and Spumella elongata. Steady-state (Days 4 to 10) densities of flagellates (cells ml ${ }^{-1} \times$ $10^{3}$ ) and bacteria (cells $\mathrm{ml}^{-1} \times 10^{6}$ ) and $P$. malhamensis $\mathrm{C} \mathrm{cell}^{-1}$ gained by photosynthesis compared to that gained by bacterial ingestion (\%) in semi-continuous cultures. Calculations of cellular volume $\left(\mu \mathrm{m}^{3} \mathrm{cell}^{-1}\right)$, flagellate biomass $\left(\mu \mathrm{m}^{3} \times 10^{3} \mathrm{ml}^{-1}\right)$, and $($ for P. malhamensis) chl a per volume unit ( $\mathrm{fg} \mathrm{chl} a \mathrm{\mu m}^{-3}$ ) were performed with cells sampled on Day 10. Low, Med, High: density of bacteria added $\left(\times 10^{6}\right) ; 15 \mu \mathrm{E} \mathrm{m}^{-2} \mathrm{~s}^{-1}, 155 \mu \mathrm{E} \mathrm{m}^{-2} \mathrm{~s}^{-1}$, dark: light intensity. Means ( $\left.\pm 1 \mathrm{SE}\right)$ of 3 replicates are shown

\begin{tabular}{|c|c|c|c|c|c|c|c|c|}
\hline \multirow{3}{*}{ Parameter } & \multicolumn{5}{|c|}{ P. malhamensis } & \multicolumn{3}{|c|}{-S. elongata } \\
\hline & \multicolumn{3}{|c|}{$-15 \mu \mathrm{E} \mathrm{m}^{-2} \mathrm{~s}^{-1}$} & \multirow{2}{*}{$\begin{array}{c}155 \mu \mathrm{E} \mathrm{m} \mathrm{m}^{-2} \mathrm{~s}^{-1} \\
\text { Med } 3.30\end{array}$} & \multirow{2}{*}{$\begin{array}{c}\text { Dark } \\
\text { Med 3.67 }\end{array}$} & \multirow{2}{*}{$\begin{array}{c}\text { Dark } \\
\text { Low } 1.46\end{array}$} & \multirow{2}{*}{$\begin{array}{l}\text { Dark } \\
\text { Med } 4.13\end{array}$} & \multirow{2}{*}{$\begin{array}{c}\text { Dark } \\
\text { High } 10.68\end{array}$} \\
\hline & Low 0.54 & Med 2.44 & High 8.18 & & & & & \\
\hline Flagellate density & $6.1(1.4)$ & $7.7(1.5)$ & $62.2(7.6)$ & $22.7(2.1)$ & $10.4(1.5)$ & $20.8(8.2)$ & $40.4(5.6)$ & $132.0(18.0)$ \\
\hline Flagellate biomass & $714(8)$ & $1147(152)$ & $5101(610)$ & $1921(155)$ & $402(37)$ & $96(18)$ & $228(18)$ & $933(47)$ \\
\hline Bacteria density & $0.57(0.07)$ & $0.74(0.09)$ & $1.12(0.33)$ & $0.55(0.13)$ & $0.76(0.12)$ & $1.10(0.39)$ & $0.54(0.10)$ & $0.82(0.16)$ \\
\hline Carbon gain & 79 & 3 & 8 & 30 & 0.3 & & & \\
\hline Volume & $92(12)$ & $102(3)$ & $93(9)$ & $92(11)$ & $56(7)$ & $7.7(0.6)$ & $6.8(0.5)$ & $8.1(0.5)$ \\
\hline Chl a & 9.43 & 5.94 & 4.96 & 2.10 & 2.28 & & & \\
\hline
\end{tabular}



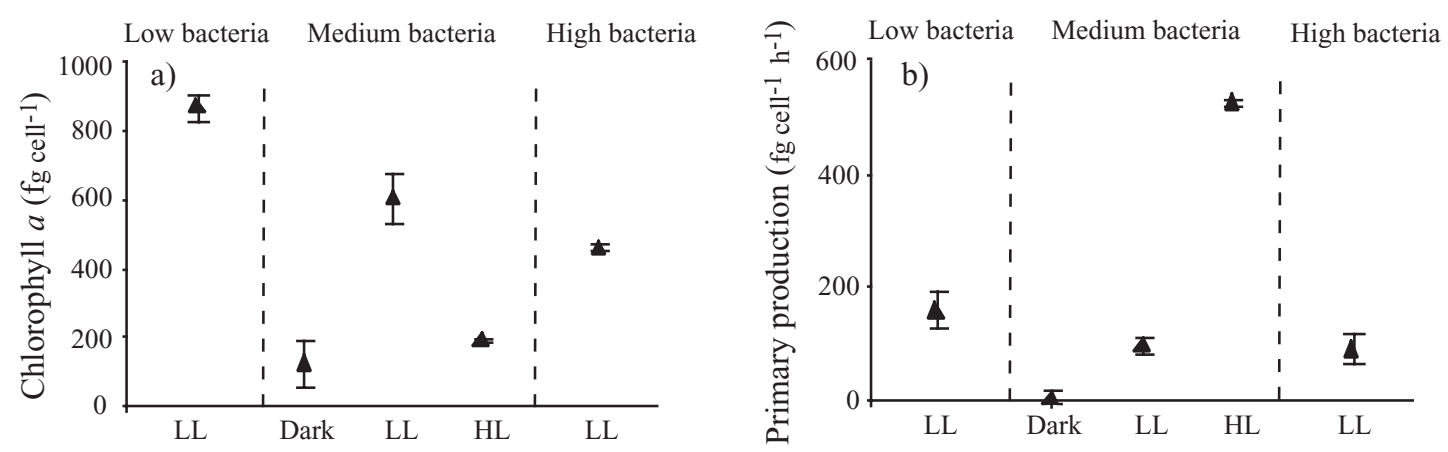

Fig. 2. Poterioochromonas malhamensis. Comparison of (a) cell-specific chl a concentrations and (b) primary production rates (in terms of C) on Day 10 in response to low (LL) and high (HL) light intensity and to darkness, with low, medium or high bacterial densities in semi-continuous culture. Note differences during exposure to different bacterial densities but identical light regime. Light intensities as in Fig. 1, bacterial densities as in Table 2. All values are means $\pm 1 \mathrm{SE}(\mathrm{n}=3)$

$\left(\mathrm{p}<0.001, \mathrm{R}^{2}=0.98\right)$. However, the biomass obtained in the $P$. malhamensis dark treatment $\left(402 \times 10^{3} \mu \mathrm{m}^{3}\right.$ $\mathrm{ml}^{-1}$ ) was considerably lower compared to the treatments receiving similar bacterial densities and light (ANOVA, $\mathrm{p}<0.001$ ). Partly, this was a result of less volume cell ${ }^{-1}$ in the dark $\left(56 \mu^{3}\right.$ cell $\left.^{-1}\right)$ compared to the

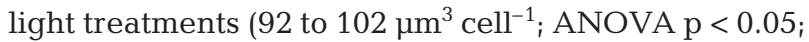
Table 2). Spumella volume cell ${ }^{-1}$ did not vary significantly between the treatments $\left(6.81\right.$ to $8.06 \mu^{3} \mathrm{cell}^{-1}$; ANOVA, $\mathrm{p}>0.05$; Table 2).

Bacterial densities in the semi-continuous cultures decreased rapidly due to flagellate grazing and reached minimum values around Day 3. After this point, bacterial densities increased somewhat, especially in the Spumella elongata low-bacteria treatment. In the Poterioochromonas malhamensis cultures, the mean bacterial densities on Days 4 to 10 varied between 0.55 and $1.12 \times 10^{6}$ cells ml $^{-1}$ (Table 2). For $S$. elongata, the corresponding densities were 0.54 to $1.10 \times 10^{6}$ cells ml$^{-1}$ (Table 2 ).

\section{Cellular production rates and chlorophyll a concentrations}

The interacting effects of bacterial density and light on Poterioochromonas malhamensis' reliance on phagotrophy versus photosynthesis is apparent when primary production rates and chl $a$ are calculated on a per cell basis. The production rate cell ${ }^{-1}$, based on ${ }^{14} \mathrm{C}$ uptake, was significantly higher in the low-light:lowbacteria treatment (162 fg C cell ${ }^{-1} \mathrm{~h}^{-1}$; ANOVA, $\mathrm{p}<$ $0.01)$ compared to the low-light:medium-bacteria and the low-light:high-bacteria treatments $\left(99 \mathrm{fg} \mathrm{C}\right.$ cell $^{-1}$ $\mathrm{h}^{-1}$ and $93 \mathrm{fgC}$ cell $^{-1} \mathrm{~h}^{-1}$ respectively; Fig. $2 \mathrm{~b}$ ). As expected, the cellular production rates were highest in the high-light treatment (526 fg C cell ${ }^{-1} \mathrm{~h}^{-1}$ ) and very low in the dark treatment $\left(7 \mathrm{fg} C\right.$ cell $\left.^{-1} \mathrm{~h}^{-1}\right)$. The $\mathrm{C}$ gained by photosynthesis varied between 0.3 and $79 \%$ of the $\mathrm{C}$ gained by bacterial ingestion, with the highest percentages in the high-light:medium-bacteria and low-light:low-bacteria treatments (30 and $79 \%$ respectively, Table 2). Cell-specific chl a decreased in all treatments during the first $36 \mathrm{~h}$ and then stabilized after approximately $84 \mathrm{~h}$. Cells of $P$. malhamensis also differed between the treatments in respect to chl $a$ cell $^{-1}$ on Day 10 (ANOVA, p < 0.001) in that a higher cell-specific chl a (chl a) concentration resulted when $P$. malhamensis was provided with low bacterial densities. The highest concentration was in the lowlight:low-bacteria treatment (864 fg chl $a$ cell ${ }^{-1}$; Fig. 2a) followed by the low-light:medium-bacteria treatment (605 $\mathrm{fg} \mathrm{chl} \mathrm{a} \mathrm{cell}^{-1}$ ) and the low-light:high-bacteria treatment (462 fg chl a cell-1 ${ }^{-1}$, whereas cellular concentrations were considerably lower in the high-light treatment (194 fg chl a cell ${ }^{-1}$ ) and the dark treatment (128 fg chl a cell ${ }^{-1}$ ). When normalized to cell volume, the ratio was $9.4 \mathrm{fg} \mathrm{chl} \mathrm{a} \mathrm{um}^{-3}$ in the low-bacteria treatment and $5.0 \mathrm{fg} \mathrm{chl} \mathrm{a} \mathrm{mm}^{-3}$ in the high-bacteria treatment (Table 2).

\section{Ingestion rates}

In both Poterioochromonas malhamensis and Spumella elongata, bacterial ingestion rates were regulated by bacterial densities. The lowest ingestion rates were measured in the low-bacteria treatments (15 bacteria cell ${ }^{-1} \mathrm{~h}^{-1}$ for P. malhamensis and 18 bacteria cell ${ }^{-1} \mathrm{~h}^{-1}$ for $S$. elongata) and the highest in the high-bacteria treatments (44 and 53 bacteria cell ${ }^{-1} \mathrm{~h}^{-1}$ respectively; Fig. 3). In $P$. malhamensis, bacterial ingestion rates also differed somewhat between the treatments receiving similar bacterial densities, and 

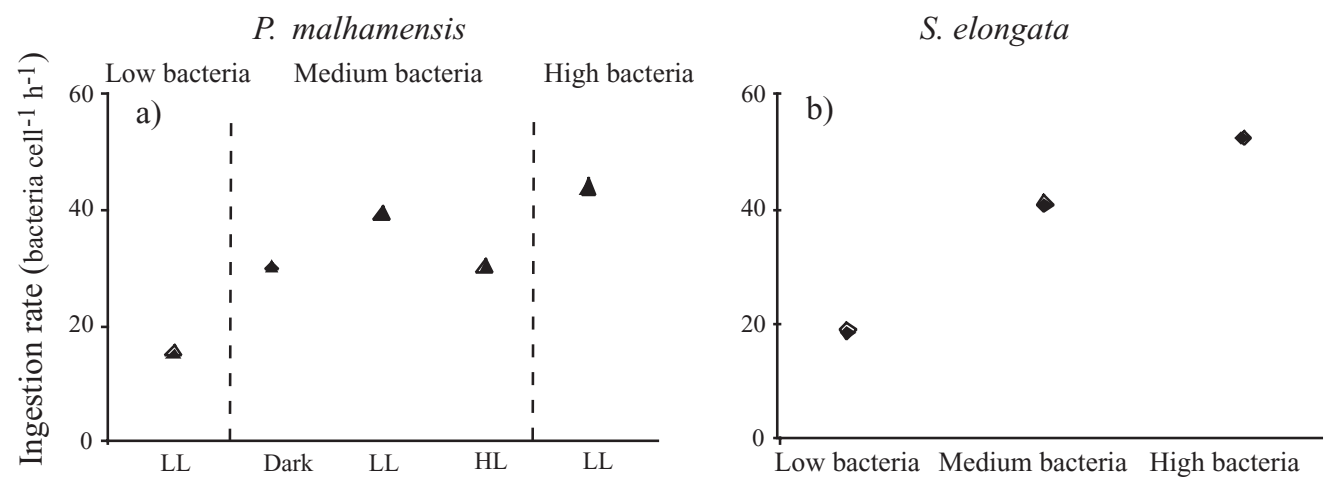

Fig. 3. Poterioochromonas malhamensis and Spumella elongata. Ingestion rates on Day 10 of (a) the mixotroph, in response to low (LL) and high (HL) light intensity and to darkness, and (b) the heterotroph, both in semi-continuous cultures with low, medium or high bacterial densities. Light levels as in Fig. 1, bacterial densities as in Table 2

the rates were lower in both the high-light and dark treatments (approximately 30 bacteria cell ${ }^{-1} \mathrm{~h}^{-1}$ ) compared to the low-light:medium-bacteria treatment (39 bacteria cell ${ }^{-1} \mathrm{~h}^{-1}$ ).

\section{DISCUSSION}

This study has shown that in semi-continuous cultures both cellular photosynthetic rates and chl a concentrations of Poterioochromonas malhamensis were influenced by bacterial densities. Thus, based on our results, we suggest that photosynthesis in $P$. malhamensis may be of greater importance than previously indicated, especially when considering nutrition at bacterial densities likely to be experienced under natural conditions. Furthermore, when provided with similar bacterial densities, the presence of light enabled this mixotroph to achieve a higher biomass than in the dark. In addition, the biomass of $P$. malhamensis in the light treatments was significantly higher than the biomass of Spumella elongata provided with similar bacterial densities, most probably as a result of $P$. malhamensis' supplementary capability for photosynthesis.

\section{Phagotrophy versus phototrophy in Poterioochromonas malhamensis}

In previous studies, the high dependence of Poterioochromonas malhamensis on phagotrophy has been well documented, and photosynthesis has been reported to contribute little to $P$. malhamensis nutrition (Caron et al. 1990, Sanders et al. 1990). However, in our study, the ability of $P$. malhamensis to compensate for low prey densities with phototrophy was apparent under steady-state conditions in the semi-continuous cultures performed, as indicated by its cellular chl a concentrations and photosynthetic rates. Cellular chl a concentrations of $P$. malhamensis decreased initially in all treatments, presumably as a result of high bacterial densities in the cultures during this period. In addition, cell-specific chl a concentrations also differed on Day 10 between treatments receiving a similar light intensity but different bacterial densities. Few studies have examined the effect of phagotrophy on cellular chl a concentrations; however, Sanders et al. (1990) found that the chl a content of $P$. malhamensis was reduced by as much as 93 to $99 \%$ when the mixotroph was exposed to food in excess. A decrease in cell-specific chl $a$ as a result of prey ingestion has also been reported for the dinoflagellate Fragilidium subglobosum (Hansen et al. 2000). Although there may be active degradation of chl $a$ in $P$. malhamensis exposed to high bacterial densities (Holen 2001), lower cellular chl a concentrations in response to phagotrophy appear primarily to be a result of higher growth rates caused by feeding, i.e. the chlorophyll is diluted due to rapid growth (Holen 1999, Hansen et al. 2000). Probably, the initial decrease in $P$. malhamensis cellular chl a concentrations was a result of dilution. However, differential growth rates cannot explain the differences found between the treatments on Day 10. Thus, P. malhamensis also seemed to adjust its cellular concentrations of chl a as a result of prey density independent of growth rate. This is evident from the concentration of chl a per unit volume ( $\mathrm{chl} a \mathrm{~m}^{-3}$ ), which was nearly twice as high in the low-bacteria than in the high-bacteria treatment, despite similar growth rates and an identical light regime.

In the semi-continuous cultures, photosynthetic rates also appeared to be influenced by prey density, as the production rate was almost twice as high in the lowbacteria treatment as in the high-bacteria treatment 
despite identical light conditions. Based on the measured photosynthetic rates, the $\mathrm{C}$ acquired by photosynthesis corresponded to $79 \%$ of the $\mathrm{C}$ acquired from bacterial ingestion in the low-light:low-bacteria treatment compared to 3-8\% when exposed to medium and high bacterial densities. In addition, it corresponded to $30 \%$ of the $\mathrm{C}$ gained by bacterial ingestion in the treatment with high light intensity, suggesting that the dependence of $P$. malhamensis on photosynthesis can be high in conditions with low bacterial densities and high light intensity. Photosynthesis in P. malhamensis has been suggested to be a long-term survival strategy to supplement nutritional needs and appears to be of little importance when prey densities are high, as is exemplified by the study of Sanders et al. (1990), who found that even at maximum photosynthetic rate, photosynthesis accounted for only $7 \%$ of the total carbon budget. Although we may have underestimated the $\mathrm{C}$ acquired by bacterial ingestion (as no bacterial growth was assumed), the reliance on photosynthesis for carbon acquisition in $P$. malhamensis was considerably higher in our study. This discrepancy might be due to the considerably higher bacterial densities (>5 $\times 10^{7}$ cells ml ${ }^{-1}$ ) used by Sanders et al. (1990). Furthermore, the reliance on phagotrophy versus phototrophy could differ between strains and, as pointed out by Holen (1999), could be related to the previous culture conditions. Based on our results, we suggest that in natural environments, where growth rates are usually well below the maximum rates achieved in laboratory experiments (Weisse 1997), photosynthetic nutrition may be more important in $P$. malhamensis than previously suggested, especially in environments with low bacterial densities and high light availability. This is further illustrated by the positive effect of light on $P$. malhamensis cell yield and biomass in the semicontinuous cultures, which is in agreement with the results of Rothhaupt (1996b) and Zhang \& Watanabe (2001), working with Ochromonas sp.

\section{Comparison of Poterioochromonas malhamensis and Spumella elongata}

A mixotrophic nutrition has not only benefits, but is also believed to incur higher basal metabolic costs, as discussed by Holen \& Boraas (1995) and Raven (1995, 1997). The most obvious of these costs is that of synthesizing both the photosynthetic and phagotrophic apparatus, and it has been suggested that mixotrophs have lower growth rates compared to specialized competitors as a result. The growth rates of Spumella elongata were higher than those of Poterioochromonas malhamensis in both the semi-continuous and batch $\left(\mu_{\max }\right)$ cultures. It is possible that the lower growth rates of the mixotroph relative to the heterotroph are a result of the mixed mode of nutrition in the former. However, in $P$. malhamensis, which grows very slow phototrophically in inorganic medium without prey (Sanders et al. 1990, Holen 1999), the photosynthetic apparatus is believed to constitute only a small fraction of the biomass, and therefore to incur low extra metabolic cost (Raven 1997). This would especially be the case in dark cultures, and is supported by the yield for growth calculated for dark batch cultures, which indicates the high phagotrophic efficiency of $P$. malhamenis. The yield in terms of biomass (C) was slightly higher for $P$. malhamenis than for $S$. elongata, and estimated yields for both species agree well with the yields (recalculated to take differences in volume into account) for heterotrophic flagellates presented by Eccleston-Parry \& Leadbeater (1994) and Ishigaki \& Sleigh (2001). However, yield may have been overestimated due to bacterial growth in the flagellate cultures. P. malhamensis did not appear to be subjected to high extra metabolic costs in the semi-continuous light treatments, as the growth rates did not differ from those in the semi-continuous dark treatment. Hence, another possibility is that the lower growth rates of this mixotroph relative to its heterotrophic competitor are related to the considerably larger cell size of $P$. malhamensis. In the mixed batch cultures, densities of $S$. elongata decreased rapidly even though fairly high densities of bacteria remained in the cultures. Probably, the decrease in $S$. elongata was a result of predation on the heterotroph by $P$. malhamensis; this was supported by microscopic observations of $P$. malhamensis containing ingested $S$. elongata cells.

Despite lower growth rates, the biomass achieved by Poterioochromonas malhamensis in the semi-continuous cultures when light was accessible was significantly higher than that of $S$. elongata provided with similar bacterial densities. These results are in agreement with those of Rothhaupt (1996a), who found that a Spumella sp. was not able to achieve equally high densities and biomass as Ochromonas sp. ingesting the same amount of bacteria. The higher biomass of $P$. malhamensis is probably due to its capacity for photosynthesis; this is supported by the field study of Bergström et al. (2003), who found that the mixotrophic biomass in a humic lake was correlated with light intensity. Furthermore, they reported that mixotrophic flagellates (mainly Ochromonas sp. and Chromulina sp.) dominated over heterotrophic flagellates at light intensities $>10 \mu \mathrm{mol} \mathrm{m} \mathrm{m}^{-2} \mathrm{~s}^{-1}$ (Bergström et al. 2003). They suggested that the dominance of mixotrophs over heterotrophs may thus be primarily light-dependent and that the ability to use light for photosynthesis gives a significant advantage to mixotrophic flagellates relative to heterotrophic flagellates. In addition to light 
intensity, bacterial densities are also believed to affect the competitive relationship between obligate heterotrophs and mixotrophs, and it has been suggested that the latter dominate only when prey concentrations are low and light is available (Jones 2000). In our study, we used bacterial densities commonly found in oligotrophic to mesotrophic lakes. However, the bacteria used were larger (mean volume $0.302 \mu^{3}$ ) than natural bacteria (0.025 to $0.08 \mathrm{\mu m}^{3}$; Wetzel \& Likens 1991). In addition, as a result of the semi-continuous mode of the cultures, bacterial densities were grazed down to low levels prior to each addition. Thus, the mixotroph may have been favored over the heterotroph, as $P$. malhamensis had a slightly lower threshold for positive growth than $S$. elongata in the batch cultures.

In mixotrophic phytoflagellates, the influence of light on ingestion rates varies greatly; in some species ingestion rate is inversely proportional to light intensity, whereas in others it is proportional to light intensity (Jones 1997). In Poterioochromonas malhamensis, ingestion rates typically increase with increasing prey abundance (Sanders et al. 1990, this study), however, the effect of light on ingestion rates varies. Light had no effect on ingestion rates in the $P$. malhamensis strain (UTEX L 1297) used by Caron et al. (1990) and Sanders et al. (1990), whereas Holen (1999) found an inverse relationship between light and ingestion rates in a newly isolated strain from Lake Lacawac (PA, USA). In yet another strain from the Shishitsuka Pond (Japan), phagotrophy was light-dependent (Zhang \& Watanabe 2001). In this study, using the same strain of P. malhamensis as that used by Holen (1999), ingestion rates appeared to be affected by the prevailing light conditions. Possibly, the negative effect of high light as well as darkness on ingestion rates was a result of the long incubation time prior to measuring grazing rates. Thus, P. malhamensis was well adapted to the prevailing conditions. However, the measured differences are small, and therefore within the natural variation expected when using the addition of a stained or artificial prey to measure ingestion rates in small protists (Weisse 2002). Although this method is commonly used, it is based on the assumption that the added prey is ingested and digested at the same rate as natural bacteria, which may not always be the case (McManus \& Okubo 1991, Weisse 2002). However, the ingestion rates measured for P. malhamensis and Spumella elongata in this study agrees well with literature values (Caron et al. 1990, Sanders et al. 1990, Weisse 2002), when taking differences in prey densities into account.

We conclude that, although primarily heterotrophic, carbon acquisition by phototrophy may contribute considerably to growth of Poterioochromonas malhamensis in environments with low bacterial densities and a high light availability. In addition, nutrition in P. mal- hamensis does not appear to be connected to large extra costs relative to those of the heterotroph Spumella elongata, and the presence of light enables this mixotroph to dominate in terms of biomass over the heterotroph when low to medium bacterial densities are provided.

Acknowledgements. This work was supported by grants from the Brazilian Research Council (CNPq) to C.D., the Royal Physiographic Society in Lund to C.P. and the Swedish Research Council to Wilhelm Granéli. We thank D. A. Holen for providing the Poterioochromonas malhamensis culture and W. Granéli, K. Rengefors and E. Granéli for commenting on an earlier version of the manuscript.

\section{LITERATURE CITED}

Auer B, Arndt H (2001) Taxonomic composition and biomass of heterotrophic flagellates in relation to lake trophy and season. Freshw Biol 46:959-972

Bennett SJ, Sanders RW, Porter KG (1990) Heterotrophic, autotrophic, and mixotrophic nanoflagellates: seasonal abundances and bacterivory in a eutrophic lake. Limnol Oceanogr 35:1821-1832

Bergström AK, Jansson M, Drakare S, Blomqvist P (2003) Occurrence of mixotrophic flagellates in relation to bacterioplankton production, light regime and availability of inorganic nutrients in unproductive lakes with differing humic contents. Freshw Biol 48:868-877

Bird DF, Kalff J (1987) Algal phagotrophy: regulating factors and importance relative to photosynthesis in Dinobryon (Chrysophyceae). Limnol Oceanogr 32:277-284

Bratvold D, Srienc F, Taub SR (2000) Analysis of the distribution of ingested bacteria in nanoflagellates and estimation of grazing rates with flow cytometry. Aquat Microb Ecol 21:1-12

Caron DA, Porter KG, Sanders RW (1990) Carbon, nitrogen, and phosphorus budgets for the mixotrophic phytoflagellate Poterioochromonas malhamensis (Chrysophyceae) during bacterial ingestion. Limnol Oceanogr 35:433-442

del Giorgio P, Bird DF, Prairie YT, Planas D (1996) Flow cytometric determination of bacterial abundance in lake plankton with the green nucleic acid stain SYTO 13. Limnol Oceanogr 41:783-789

Eccleston-Parry JD, Leadbeater BSC (1994) A comparison of the growth kinetics of six marine heterotrophic nanoflagellates fed with one bacterial species. Mar Ecol Prog Ser 105:167-177

Fry JC (1988) Determination of biomass. In: Austin B (ed) Methods in aquatic bacteriology. John Wiley \& Sons, Chichester

Granéli E, Carlsson P (1998) The ecological significance of phagotrophy in photosynthetic flagellates. NATO ASI Ser Ser G Ecol Sci 41:539-557

Guillard RRL, Lorenzen CJ (1972) Yellow-green algae with chlorophyllide $C$. J Phycol 8:10-14

Handa AK, Bressan RA, Quader H, Filner P (1981) Association of formation and release of cyclic AMP with glucose and onset of chlorophyll synthesis in Poterioochromonas malhamensis. Plant Physiol 68:460-463

Hansen PJ, Skovgaard A, Glud RN, Stoecker DK (2000) Physiology of the mixotrophic dinoflagellate Fragilidium subglobosum. II. Effects of time scale and prey concentration 
on photosynthetic performance. Mar Ecol Prog Ser 201: 137-146

Hitchman RB, Jones HLJ (2000) The role of mixotrophic protists in the population dynamics of the microbial food web in a small artificial pond. Freshw Biol 43:231-241

Holen DA (1999) Effects of prey abundance and light intensity on the mixotrophic chrysophyte Poterioochromonas malhamensis from a mesotrophic lake. Freshw Biol 42:445-455

Holen DA (2001) The effects of heterotrophy on chlorophyll a and photosynthesis in a mixotrophic chrysophyte. Nova Hedwigia (Beih) 122:107-118

Holen DA, Boraas ME (1995) Mixotrophy in chrysophytes. In: Sandgren CD, Smol JP, Kristiansen J (eds) Chrysophyte algae: ecology, phylogeny and development. Cambridge University Press, Cambridge, p 119-140

Isaksson A, Bergström AK, Blomqvist $\mathrm{P}$, Jansson $\mathrm{M}$ (1999) Bacterial grazing by phagotrophic phytoflagellates in a deep humic lake in northern Sweden. J Plankton Res 21: $247-268$

Ishigaki T, Sleigh MA (2001) Grazing characteristics and growth efficiencies at two different temperatures for three nanoflagellates fed with Vibrio bacteria at three different concentrations. Microb Ecol 41:264-271

Jespersen AM, Christoffersen K (1987) Measurements of chl a from phytoplankton using ethanol as extraction solvent. Arch Hydrobiol 109:445-454

Jones HLJ (1997) A classification of mixotrophic protists based on their behaviour. Freshw Biol 37:35-43

Jones RI (2000) Mixotrophy in planktonic protists: an overview. Freshw Biol 45:219-226

Laybourn-Parry J, Parry J (1995) Flagellates and the microbial loop. In: Leadbeater BSC, Green JC (eds) The flagellates: unity, diversity and evolution. The Systematics Association Special Volume Series 59, Taylor \& Francis, London, p 216-239

Lewitus AJ, Caron DA (1991) Physiological responses of phytoflagellates to dissolved organic substrate additions. 1. Dominant role of heterotrophic nutrition in Poterioochromonas malhamensis (Chrysophyceae). Plant Cell Physiol 32:671-680

McManus GB, Okubo A (1991) On the use of surrogate food particles to measure protistan ingestion. Limnol Oceanogr 38:273-279

Myers J, Graham JR (1956) The role of photosynthesis in the physiology of Ochromonas. J Cell Comp Physiol 47: $397-414$

Nygaard K, Tobiesen A (1993) Bacterivory in algae: a survival strategy during nutrient limitation. Limnol Oceanogr 38: 273-279

Editorial responsibility: David Caron,

Los Angeles, California, USA
Raven JA (1995) Comparative aspects of chrysophyte nutrition with emphasis on carbon, nitrogen and phosphorus. In: Sandgren CD, Smol JP, Kristiansen J (eds) Chrysophyte algae: ecology, phylogeny and development. Cambridge University Press, Cambridge, p 95-118

Raven JA (1997) Phagotrophy in phototrophs. Limnol Oceanogr 42:198-205

Rothhaupt KO (1996a) Utilization of substitutable carbon and phosphorus sources by the mixotrophic chrysophyte Ochromonas sp. Ecology 77:706-715

Rothhaupt KO (1996b) Laboratory experiments with a mixotrophic chrysophyte and obligately phagotrophic and phototrophic competitors. Ecology 77:716-724

Rothhaupt KO (1997) Nutrient turnover by freshwater bacterivorous flagellates: differences between a heterotrophic and a mixotrophic chrysophyte. Aquat Microb Ecol 12:65-70

Sanders RW, Porter KG, Caron DA (1990) Relationship between phototrophy and phagotrophy in the mixotrophic chrysophyte Poterioochromonas malhamensis. Microb Ecol 19:97-109

Sanders RW, Caron DA, Davidson JM, Dennett MR, Moran DM (2001) Nutrient acquisition and population growth of a mixotrophic alga in axenic and bacterized cultures. Microb Ecol 42:513-523

Sherr EB, Sherr BF (1993) Protistan grazing rates via uptake of fluorescently labeled prey. In: Kemp PF, Sherr BF, Sherr EB, Cole JJ (eds) Handbook of methods in aquatic microbial ecology. Lewis, Boca Raton, FL, p 695-701

Starr RC (1978) The culture collection of algae at the University of Texas at Austin. J Phycol 14(Suppl):47-100

Stickney HL, Hood RR, Stoecker DK (2000) The impact of mixotrophy on planktonic marine ecosystems. Ecol Model 125:203-230

Thingstad TF, Havskum H, Garde K, Riemann B (1996) On the strategy of 'eating your competitor': a mathematical analysis of algal mixotrophy. Ecology 77:2108-2118

Weisse T (1997) Growth and production of heterotrophic nanoflagellates in a meso-eutrophic lake. J Plankton Res 19:703-722

Weisse T (2002) The significance of inter- and intraspecific variation in bacterivorous and herbivorous protists. Antonie Leeuwenhoek 81:327-341

Wetzel RG, Likens GE (1991) Limnological analyses, 2nd edn. Springer-Verlag, New York

Zhang X, Watanabe MM (2001) Grazing and growth of the mixotrophic chrysomonad Poterioochromonas malhamensis (Chrysophyceae) feeding on algae. J Phycol 37: $738-743$

Submitted: October 1, 2003; Accepted: March 8, 2004

Proofs received from author(s): July 23, 2004 